\title{
The Effect of Individual Capability, Individual Motivation, Organizational Climate, and Transformational Leadership on Pilot Performance
}

\author{
Taufik Nur Cahyanto ${ }^{1}$, Harianto Respati ${ }^{2 *}$, Mokhamad Natsir ${ }^{2}$ \\ ${ }^{\mathrm{T}}$ Student in Magister of Management, University of Merdeka Malang, Indonesia \\ ${ }^{2}$ Faculty of Economics and Business, University of Merdeka Malang, Indonesia
}

\begin{abstract}
Article History
Received: 03.12.2020

Accepted: 16.12 .2020

Published: 24.12.2020
\end{abstract}

Journal homepage:

https://www.easpublisher.com

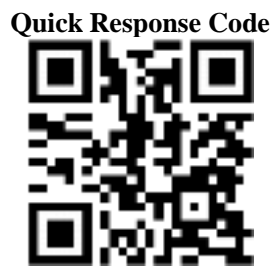

\begin{abstract}
This research aims to analyze the influence of individual capability, individual motivation, the organizational climate, and transformational leadership on the Indonesian Air Force Pilot performance at $2^{\text {nd }}$ Air Wing, "Abdulrachman Saleh" Air Force Base. The proposed hypotheses are: The individual capability has a significant influence on Pilot Job Performance, Individual Motivation have a significant influence the Pilot Job Performance, The organizational climate has a significant influence on Pilot Job Performance, The Transformational leadership has a significant influence on the Pilot Job Performance, The Individual Capability have dominance influence to the pilot job performance, especially pilot Non-technical skill (NTS). One of the most influencing factors in pilot Non-technical skill which contributes directly to the pilot job performance is Pilot Situational Awareness. The result of the research has evidenced that Pilot Job performance is supported by the achievement of safety in Flight operation. In other words, safety is one of the key factors in pilot Job performance that should be achieved by all military pilots.

Keywords: Individual capability, Individual motivation, organizational climate, transformational leadership, pilot performance.
\end{abstract}

Copyright (C) 2020 The Author(s): This is an open-access article distributed under the terms of the Creative Commons Attribution 4.0 International License (CC BY-NC 4.0) which permits unrestricted use, distribution, and reproduction in any medium for non-commercial use provided the original author and source are credited.

\section{INTRODUCTION}

Pilot in the military is one of the professions in the Indonesian Air Force, which has special specifications in carrying out their duties. The Indonesian Air Force is prepared for its capability for combat and non-combat missions. The idea of soldiers as human resources in military organizations is rational. Today a modern war is underway, a war that involves elements of the brain, called a brain war or a war of difference in excellence and a war of creativity in the political, economic, technological, cultural, and scientific arena [1]. The war of the 21 st century is called "modern warfare". The ability of individuals both cognitive and psychomotor becomes the main prerequisite, given that aircraft use advanced technology.

This research discusses pilot performance. This research was conducted at a military airbase, which was observed in was $2^{\text {nd }}$ Air Wing organization located at the "Abdulrachman Saleh" airbase. The role of human capital is to ensure that the company's success is due to the ability of individuals or groups in the company's organization (Respati and Triatmanto, 2019). Human capital for the $2^{\text {nd }}$ Air Wing organization is seen as important as an investment in human resources. Changes in the social environment in $2^{\text {nd }}$ Air Wing organizations are influenced by soldier capabilities.
Several incidents and accidents related to "flying safety" in carrying out tasks determine the pilot performance of the military in the $2^{\text {nd }}$ Air Wing unit. During the past 4 to 6 years, there were accidents with fatalities, and material losses in the 2nd Air Wing "Lanud Abdulrachman Saleh" unit, including the crash of the Hercules C-130 / A-1310 aircraft in Medan city in 2015, the crash of the EMB- 314 Super Tucano at Blimbing in 2016, and the fall of the Hercules C-130/ A-1334 aircraft at Wamena in 2016 [2].

Improved pilot performance can be achieved if the pilot has Individual Capability. Individual skills can be measured by several components such as personal capability, professional technical know-how, experience, the network range, the attitude that influences actions [3]. Besides, a pilot must fulfill the knowledge of Pilot Non-technical Skills (NTS) consisting of coordination, situational awareness, and decision making [4]. Measurement of individual capability variable, which is Pilot Non-technical Skill, is the renewal of this study. Nadeem, et al. [5] found that individual capability influences performance.

Mangkunegara [6] has explained the general view of motivational theory, which is the energy that drives the individual leads to achieving organizational goals. Motivation is formed from employee attitudes in 
dealing with work situations. Individual Motivation according to Mayo [3] consists of aspiration, ambition, and drive, work motivation, productivity. On the continuation of this theory, Nugraha et al. [7] Prove that individual motivation influences performance.

The work environment climate that is felt by individuals in an organization is called the organizational climate. Opinion by Stinger [8] has stated that organizational climate determines work motivation to have an impact on the performance of organizational members. Based on the links, the working environment in Wing 2 military organizations needs to be tested, does it affect pilot performance.

Simamora [9] explains that a conducive organizational climate provides a sense of security, and allows employees to work optimally. A conducive organizational climate is needed to support the implementation of employee duties. Organizational climate is an important factor in efforts to improve the performance of pilots in the $2^{\text {nd }}$ Air Wing. In its sequel, Junaidi and Hartono [10] have proven that organizational climate significantly influences performance. However, the results of Nugraha et al. [7] have shown that organizational climate does not affect performance. With these differing views, it is interesting to review the relationship between organizational climate and individual performance, especially the pilots on the $2^{\text {nd }}$ Air Wing unit.

In general, thoughts about the relationship between leadership and performance can be ascertained that there is a relationship. The Indonesian Air Force Pilot at $2^{\text {nd }}$ Air Wing more often applies various leadership for organizational purposes. But in this study, transformational leadership was chosen to be studied. The basis for leadership being chosen for research is to refer to the technical manuals owned by the air force. The contents of the manual explain the list of soldiers based on performance evaluation, stated in Skep / 97 / IX / 2000 stating that leadership is that an officer in carrying out tasks must be proficient in using formal authority to organize, direct, and control his subordinates with the full sense of responsibility responsible, and all parts of the work are carefully coordinated to achieve organizational goals. This means that military organizations are certain to implement leadership.

According to Bass and Avolio [11], transformational leadership is a leader who gives consideration and intellectual stimulation and has charisma. This type of leadership is more appropriate for pilots in $2^{\text {nd }}$ Air Wing units. The leader transforms and motivates his followers by making them more aware of the importance of the results of a job, encouraging them to better understand the needs of the organization or team rather than self-interest, and activating their needs at a higher level. The results of research by Rufino [12], Heru [13], and Soegiarto [14] have succeeded in proving that leadership influences performance, but the results of Nugraha et al. [7] is different than leadership does not affect performance. The difference in the results of this study became the basis for re-testing the effect of transformational leadership on individual performance, especially the pilots in the $2^{\text {nd }}$ Air Wing unit.

Based on the condition of human resources who work as pilots of the Indonesian air forces, especially in the $2^{\text {nd }}$ Air Wing Unit in realizing operational readiness of the main tasks and maintaining the sovereignty of the country in the air, the researchers are interested in testing the influence of Individual Capability, Individual Motivation, The Organizational Climate and Transformational Leadership on Pilot Performance. And also, determine the key factors for successful Pilot performance.

\section{LITERATURE REVIEW Pilot Performance}

Ruky [15] describes performance is defined as the record of outcomes produced on specified job functions or activities during the period. Achievement or performance is a record of the results of the work during a certain time. Dessler [16] argues that employee performance is the employee's actual achievement compared to the expected performance of the employee. According to Mathis and Jackson [8], employee performance is something that is informed by output quantity, output quality, output period, workplace attendance, and cooperative attitude. Mathis and Jackson [8] explain that performance is what employees do. According to Mathis and Jackson [8], performance evaluation indicators are divided into five points, namely: 1) Quantity, 2) Quality, 3) Timeliness, 4) Attendance, 5) Ability to cooperate. Also, more specific for pilot performance following ICAO annex 2 is measured by the ability of a pilot to achieve safety. Pilots have a responsibility in bringing about safety in performance.

The pilot-in-command of an aircraft shall, whether manipulating the controls or not, be responsible for the operation of the aircraft following the rules of the air, except that the pilot-in-command may depart from these rules in circumstances that render such departure necessary in the interests of safety [17]. So that flight safety is more appropriate to be used to measure the performance of a pilot. Measurement of pilot performance using flight safety indicators is part of this research novelty. This study examines pilot performance, derived from the words individual performance adjusts the thinking of Dessler [16] and Mathis and Jackson [8]. To complete the measurement of pilot performance, a safety indicator is added. So in this study, pilot performance is measured by six indicators, namely 1) Quantity, 2) Quality, 3) 
Timeliness, 4) Attendance, 5) Ability to cooperate, and 6) Safety

\section{Individual Capability}

According to Mayo [3] stated that individual capability is the ability of individuals to support the goals of the organization/team, this is seen in the implementation of tasks. Mayo [3] argues that individual capability can be measured by five criteria, namely: (1) Personal capabilities are individual abilities including appearance, thoughts, actions, and feelings. (2) Professional and technical know-how is the ability to be professional at work and able to transfer knowledge to all lines of the organization. (2) Experience is the experience of individuals in the field of work as well as an open attitude to experience. (3) The network and range of personal contacts are to have a wide network or connection with anyone, especially people who are related to their profession (4). The values of attitudes that influence actions are values and attitudes that influence actions in the work environment such as emotional stability, friendliness, being able to socialize, and being assertive.
The part that cannot be separated from the individual Capability of a pilot is the ability of Nontechnical skills or commonly known in the world of aviation that is Pilot Non-technical Skill (NTS).

Non-technical Pilot Skills are cognitive and social skills that complement technical skills, based on safety and efficiency for flight activities [4]. Nontechnical Pilot Skill is defined as the attitude and behavior of pilots that are not directly related to aircraft control, system control, and standard operating procedures (SOP).

Non-technical skills in aircraft are an authority in the cockpit, crew coordination and cooperation, communication, decision making, conflict and error management, stress and workload management, attention, alertness, and self-confidence. In short, nontechnical skills cover the social and cognitive side of a pilot. Non-technical Skill that must be possessed by a pilot as part of individual capability consists of Cooperation, Leadership \& management skills, situation awareness, and decision making.

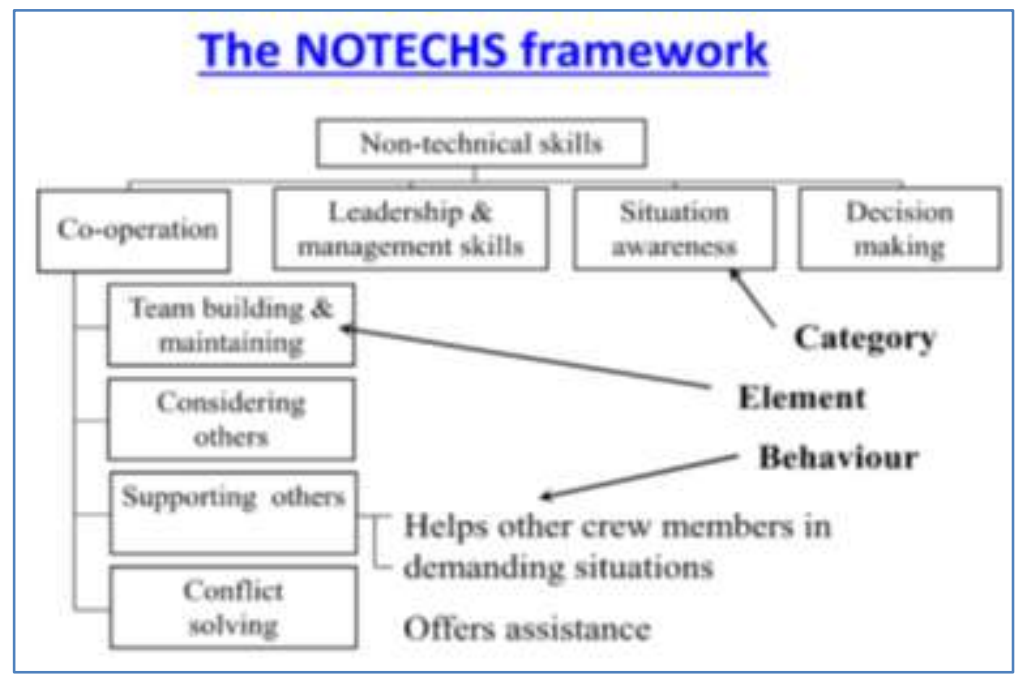

Fig-1: Model Pilot Non-technical Skill

Source: Wiener et al.[4]

NTS is one part of aviation that is often a part of crew resource management (CRM), which has been defined as "timely and professional use of aircraft resources by the operating crew" [11]. NTS plays a significant role in the occurrence of aviation accidents, and vice versa NTS also has an important role in creating resilience in the face of new threats [18]. The International Civil Aviation Organization (ICAO) has called for increased integration of NTS training for aircraft crews [19].

\section{Individual Motivation}

Mayo [3] explains the individual motivator is the desire to do work on self-awareness for organizational goals. Individual motivation consists of elements of Aspirations; ambitions and drive; work motivations; and productivity. Mangkunegara [6] explains about individual motivation is the energy of employees that leads to the achievement of corporate organizational goals. Motivation is formed from employee attitudes. Robbin [20] explains that motivation is the desire and effort of individuals for organizational goals. Fernet et al. [21] state motivation is a person's motive for doing something or not. Motivation is generally divided into two namely intrinsic and extrinsic motivations. Intrinsic motivation consists of challenge orientation and assignment. Whereas extrinsic motivation consists of compensation orientation and recognition orientation [18]. 


\section{Organizational Climate}

Organizational climate according to Stringer [22] is a collection and environmental patterns that determine motivation. Organizational climate is a person's perception of what is given by the organization and is used as a basis for determining employee behavior in work. The indicators used in organizational climate according to Stringer [22] are structure, standards, responsibilities, recognition, support, and commitment. Organizational Climate according to Mayo [3] is the culture of the organization, especially in freedom with innovation, openness, flexibility, and respect for the individual. The essential elements are freedom of innovation, openness, flexibility, and individual appreciation. Organizational climate according to Simamora [9] is related to the internal environment or organizational psychology. Organizational climate influences HR practices and policies. Each organization has a different organizational climate. The diversity of jobs and the nature of individuals illustrate the differences in organizational climate.

Stringer [22] explains in more detail the six dimensions of organizational climate measures, namely: 1) Structure. Employees must understand the roles and responsibilities clearly, and the level of decision making in the organization, 2) Standards. The level of the employee must comply with applicable work systems and procedures. 3) Responsibility. Reflect employee feelings in terms of courage used in problem-solving without considering the decisions of others, 4) Awards. Reflect the feelings of employees who receive the right reward and punishment. Members of the organization feel valued when able to complete the task well, 5) Support. Reflecting feelings of trust and mutual support among members of the organization, 5) Commitment. Reflect compliance not to violate and be loyal to the team/organization.

\section{Transformational Leadership}

Bass and Avolio [11] explain Transformational Leadership is leadership that gives consideration and stimulation and has charisma. The same thing is also according to Robbins and Judge [20] which explains that transformational leadership is a leader who gives consideration and intellectual stimulation and has charisma. According to Bass [23] also explains about transformational leadership is a condition where the followers of a transformational leader feel the existence of trust, admiration, loyalty, and respect for the leader. The leader transforms and motivates followers by making them more aware of the importance of a job, encouraging subordinates to put the organization or team more in importance than their interests. In subsequent developments, transformational leadership is described in four main characteristics, namely: the idealization of influence, inspirational motivation, individual consideration, and intellectual stimulation [23, 24, 11].

Idealized Influence is behavior that produces standards of behavior, insight, and awareness of vision, beliefs, respect, pride, and trust, and commitment. Inspirational Motivation is an attitude that fosters challenges, expectations, enthusiasm and motivation, and goodness. The leader can rise team members through enthusiasm and optimism. Individualized Consideration is a leader who listens attentively, gives special attention, support, encouragement, encourages achievement, and the growth of its members. Intellectual Stimulation is leadership that can increase understanding and stimulates the emergence of new perspectives in analyzing problems, thinking, imagining, and being able to set the values of trust.

\section{Research Methodology}

\section{Research Design}

The design of this study is causal-comparative and explanatory research with a quantitative approach. This research is expected to explain the effect of individual capability, individual motivation, organizational climate, and transformational leadership on performance. The scope of this research is the field of human resource management. Research location at the "Abdulrachman Saleh" airbase in Malang, Indonesia. Research respondents were individuals, namely the Indonesian Air Force Pilot at the $2^{\text {nd }}$ Air Wing. Research data is the answer to the research questionnaire. Respondents answered the questionnaire by choosing one of five choices namely 1 stating strongly disagree to option 5 namely stating strongly agree. Option 3 shows a neutral statement (Likert scale). The total population is 45 pilots. Census techniques are used to determine the unit of analysis.

\section{Research variables and indicators}

There are four independent variables namely individual capability, individual motivation, organizational climate, and transformational leadership. One dependent variable is pilot performance. Variables and research indicators are presented in Table 1. 
Table-1: Variables, and research indicators

\begin{tabular}{|c|c|c|}
\hline Variables & Indicators & Reference \\
\hline \multirow[t]{6}{*}{ X1- Individual capability } & X11- Personal capability & \multirow{6}{*}{$\begin{array}{l}\text { Mayo, 2000; [3] } \\
\text { Wiener et } \\
\text { al.,2010 [4] }\end{array}$} \\
\hline & X12 -Profesional and technical know-how & \\
\hline & X13- Experience & \\
\hline & X14- The network and range of personal contact & \\
\hline & X15- The attitudes that influence actions & \\
\hline & X15- Pilot Non-Technical Skill (NTS) & \\
\hline \multirow[t]{4}{*}{ X2- Individual Motivation } & X21- Aspirations & \multirow[t]{4}{*}{ Mayo,2000 [3] } \\
\hline & X22 - Ambitions and drive & \\
\hline & X23- Work motivations & \\
\hline & X24 - Productivity & \\
\hline \multirow[t]{6}{*}{ X3- Organizational climate } & X31- Struktur & \multirow[t]{6}{*}{ Stringer,2002 [22] } \\
\hline & X32- Standards & \\
\hline & X33- responsibility & \\
\hline & X34- Recognition & \\
\hline & X35- Support & \\
\hline & X36- Commitment & \\
\hline \multirow{4}{*}{$\begin{array}{l}\text { X4-Transformational } \\
\text { leadership }\end{array}$} & X41- Idealized Influence & \multirow{4}{*}{$\begin{array}{l}\text { Bass and Avilio } \\
1993 \text { [23] }\end{array}$} \\
\hline & X42- Inspirational motivation & \\
\hline & X43- Individualized consideration & \\
\hline & X44- Intellectual stimulation & \\
\hline \multirow[t]{6}{*}{ Y - Pilot performance } & Y1- Quantity & \multirow{6}{*}{$\begin{array}{l}\text { Mathis and } \\
\text { Jackson [8], } \\
\text { ICAO ANNEX } 2 \\
{[17]}\end{array}$} \\
\hline & Y2- Quality & \\
\hline & Y3- Punctuality & \\
\hline & Y4- Presence & \\
\hline & Y5- The ability to cooperate & \\
\hline & Y6- Safety & \\
\hline
\end{tabular}

\section{Conceptual framework and analysis techniques}

The research concept framework is presented in Figure 2.

The structural equation model built is:

$\mathrm{Y}=\mathrm{b} 1 \mathrm{X} 1+\mathrm{b} 2 \mathrm{X} 2+\mathrm{b} 3 \mathrm{X} 3+\mathrm{b} 4 \mathrm{X} 4+\mathrm{e}$

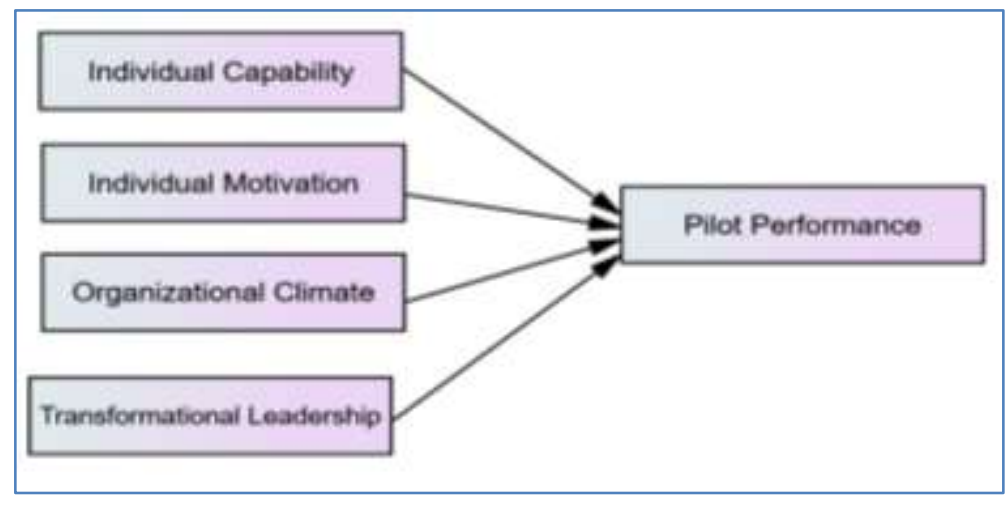

Fig-2: Conceptual framework

H1. Individual capability has a significant positive effect on pilot performance

$\mathrm{H} 2$. Individual motivation has a significant positive effect on pilot performance

H3. Climate organization has a significant positive effect on pilot performance

H4. Transformational leadership has a significant positive effect on pilot performance

Data analysis techniques using correlation techniques and multiple linear regressions. There are validity and reliability testing for instrument testing and descriptive analysis to explain the respondents' perceptions. Technical analysis of data using the SPSS program.

\section{RESEARCH RESULT}

Description of Respondent Characteristics

Characteristics of research respondents as follows:

1. All respondents are male. 
2. The composition of $35.6 \%$ is aged between $32-38$ years.

3. The composition of $40 \%$ are respondents educated with a degree

4. The working period of respondents, 1-5 years is $17.8 \%$. 6 - 10 years 15 is $33.3 \%$.

Respondents with a service period of more than 10 years are $48.9 \%$. This percentage explains that most respondents worked for more than 10 years. This hall shows that respondents are very familiar with the type and diversity of work.

\section{Descriptive Analysis of Research Variables}

Univariate statistics explain the mean value to measure respondents' perceptions. Results Analysis of descriptions for the five variables studied is presented in Table 2.

Table-2: Results of analysis of variable descriptions, and research indicators

\begin{tabular}{|c|c|c|}
\hline Variables & Indicators & mean \\
\hline \multirow{6}{*}{$\begin{array}{l}\text { X1- Individual capability } \\
(4,17)\end{array}$} & X11- Personal capability & 4,16 \\
\hline & X12 -Profesional and technical know-how & 4,18 \\
\hline & X13- Experience & 4,12 \\
\hline & X14- The network and range of personal contact & 4,10 \\
\hline & X15- The attiudes that influence actions & 4,16 \\
\hline & X15- Pilot Non-Technical Skill (NTS) & 4,29 \\
\hline \multirow{4}{*}{$\begin{array}{l}\text { X2- Individual Motivation } \\
\qquad(4,23)\end{array}$} & X21- Aspirations & 4,23 \\
\hline & $\mathrm{X} 22$ - Ambitions and drive & 4,24 \\
\hline & X23- Work motivations & 4,29 \\
\hline & X24 - Productiviy & 4,18 \\
\hline \multirow{6}{*}{$\begin{array}{l}\text { X3- Organizational } \\
\text { climate. } \\
(4,10)\end{array}$} & X31- Struktur & 4,32 \\
\hline & X32- Standards & 3,58 \\
\hline & X33- responsibility & 4,14 \\
\hline & X34- Recognition & 4,13 \\
\hline & X35- Support & 4,26 \\
\hline & X36- Commitment & 4,17 \\
\hline \multirow{4}{*}{$\begin{array}{l}\text { X4-Transformational } \\
\text { Leadership. } \\
(4,10)\end{array}$} & X41- Idealized Influence & 4,12 \\
\hline & X42- Inspirational motivation & 4,03 \\
\hline & X43- Individualized consideration & 4,16 \\
\hline & X44- Intellectual stimulation & 4,06 \\
\hline \multirow{6}{*}{$\begin{array}{c}\text { Y - Pilot performance } \\
(4,34)\end{array}$} & Y1- Quantity & 4,13 \\
\hline & Y2- Quality & 4,21 \\
\hline & Y3- Punctuality & 4,27 \\
\hline & Y4- Presence & 4,29 \\
\hline & Y5- The ability to cooperate & 4,34 \\
\hline & Y6- Safety & 4,82 \\
\hline
\end{tabular}

\section{Classic Assumption Test Results}

To obtain an unbiased and efficient estimator value from a multiple regression equation with the Ordinary Least Square approach, it is necessary to present the results of the classical assumption test of multiple linear regression as follows:

\section{a. Multicollinearity and Autocorrelation}

Multicollinearity testing uses the comparison of VIF and number 5 as tolerance values. Autocorrelation testing uses the Durbin Watson (DW) value. The results of the analysis assisted with the SPSS program are presented in Table 3.

Table-3: Multicollinearity Test Results

\begin{tabular}{|l|l|l|}
\hline Research variable & VIF & DW \\
\hline Individual capability & 2,794 & \multirow{2}{*}{1,95} \\
\cline { 1 - 2 } Individual motivation & 2,888 & \\
\cline { 1 - 2 } Organizational climate & 2,909 & \\
\cline { 1 - 2 } Transformational leadership & 1,694 & \\
\hline
\end{tabular}

The VIF value shows that the Individual capability, individual motivation, organizational climate, and transformational leadership variables do not exceed 5, and the DW value is between -2 and 2 . This comparison explains that the multiple linear regression equation models are free from multicollinearity and autocorrelation problems. This means that the measured variable shows a good level of precision in the measurement, and each unit of analysis that is measured serially between one and another does not affect the other.

\section{b. Normality}

Normally distributed data is one of the important assumptions in researching with regression. To detect the normality of data can be done by observing the spread of data (points on the diagonal axis of the graph, if the data spreads around the diagonal line and follows the direction of the diagonal line, this shows that the data has been normally distributed). 


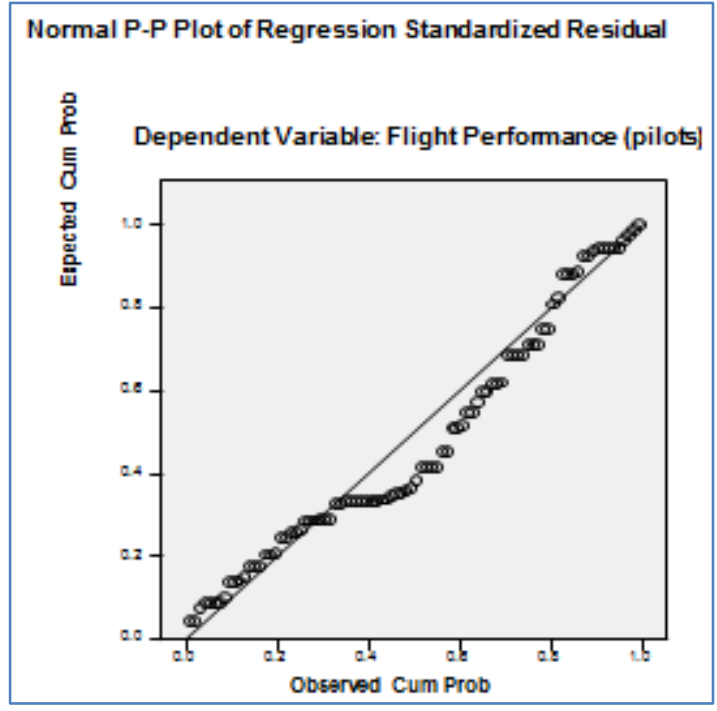

Fig-3: Data Normality

Figure 3. Shows that data (points) spread around and approach the diagonal line. This shows that the research data namely Individual capability, individual motivation, organizational climate, and transformational leadership are normally distributed.

\section{c. Heteroscedasticity}

Heteroscedasticity explains the variation in residuals that are not the same for all observations. To detect the symptoms of heteroskedasticity using scatterplots, the results of the heteroscedasticity test are presented in Figure 4.

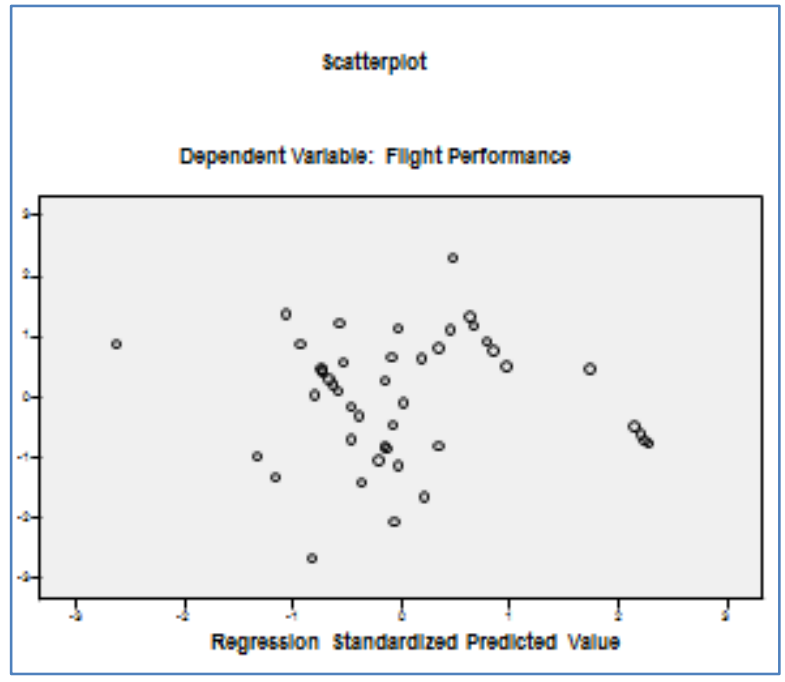

Fig-4: Heteroscedasticity test results

Figure 3 shows the scattered points randomly, does not form a specific clear pattern, and is spread both above and below the number 0 on the $\mathrm{Y}$-axis. This distribution shows there is no heteroscedasticity in the regression model.

\section{Multiple Regression Analysis}

The results of data processing using the SPSS 15 computer program for windows obtained the analysis results as in Table 4.

Table-4: Recapitulation of Multiple Linear Regression Analysis Results

\begin{tabular}{|c|c|c|c|c|}
\hline Independent variable & Dependent variable & Regression Coefficient & Sig. & Note \\
\hline Individual capability $\left(\mathrm{X}_{1}\right)$ & \multirow{4}{*}{ Pilot Performance } & 0,398 & 0,001 & H1 - be accepted \\
\hline Individual motivation $\left(\mathrm{X}_{2}\right)$ & & 0,253 & 0,037 & H1 - be accepted \\
\hline Organizational climate $\left(\mathrm{X}_{3}\right)$ & & 0,229 & 0,036 & H1 - be accepted \\
\hline Transformational leadership $\left(\mathrm{X}_{4}\right)$ & & 0,156 & 0,039 & H1 - be accepted \\
\hline Adjusted R square & & & & 0,912 \\
\hline $\mathrm{F}-$ statistic & & & & 49,216 \\
\hline Sig. F & & & & 0,000 \\
\hline
\end{tabular}

Model of multiple linear regression equations: $Y=0,057+0,398 X_{1}+0,253 X_{2}+0,229 X_{3}+0,156 X_{4}+e$

The probability value of the model shows that producing a value of 0,000 is still below the error rate of error of $5 \%$, meaning that resulting the multiple linear regression equation models can be accepted as an analysis tool with a contribution rate of $91.2 \%$. There are $9.9 \%$ for other independent variables not calculated in the regression model.

\section{DiscuSSION}

Individual capability is formed by personal capabilities, professional technical know-how, experience, the network range of personal contacts, the attitudes that influence actions, and Pilot Non-Technical Skills (NTS). According to respondents' perceptions, the subject of Individual capability, namely NonTechnical Skill (NTS) is reflected in the ability of pilots in the situation of "Awareness" in-flight implementation. Individual capability plays a major role in carrying out various cognitive tasks and physical abilities. Mayo [3] argues that individual capability is the ability of individuals to support individual performance and ultimately support the performance of an organization. This occurs in the implementation of flight assignments.

Individual motivation is formed by aspirations, ambitions and drive, work motivation, and productivity. The main thing that builds individual motivation for pilots is work motivation. This is reflected in the 
discipline motivation of the pilots, namely the motivation to be directed, and the ability to maintain behavior. Aviators are highly motivated to do their best, are confident in their ability to work independently, and be optimistic, have a great responsibility for every action.

Organizational Climate is formed by structure, standards, responsibilities, recognition, support, and commitment. According to respondents' perceptions about Organizational Climate is a structure, reflected by each pilot who has a role and responsibility for functions within the team/organization.

Transformational Leadership is formed by Idealized influence, Inspirational motivation, Individualized consideration, and Intellectual stimulation. Considering the results of the analysis on the four measurements, according to respondents' perceptions Transformational Leadership is formed by Individualized consideration. The leadership, enthusiasm, and effort support for achievement needs are the priority of pilots.

Pilot performance is shaped by quantity, quality, timeliness, attendance, ability to cooperate, and safety. The main thing that shapes pilot performance is safety. The principle of safety in carrying out tasks is a top priority for pilots. Flight safety is the most important thing in operating an aircraft.

\section{Individual capability and pilot performance}

The results of the study prove that Individual capability can improve pilot performance. NonTechnical Pilot Skills are reflected in the capabilities of a pilot in collaboration with fellow aircrew and ground crew, the ability to pay close attention to Situational Awareness in carrying out flights, and the ability to make decisions (decision making) has been proven to improve performance. Non-technical skills Pilots are cognitive and social skills that complement technical skills and contribute to safe and efficient task performance for a pilot [4]. Non-technical skills are defined as the attitudes and behavior of pilots that are not directly related to aircraft control, system control, and standard operating procedures (SOP). The results showed that a high level of education and tenure above 10 years had a close correlation in achieving the ability of pilots of non-technical skills, especially Situational Awareness.

\section{Individual motivation and pilot performance}

The results of the study have proven that Individual motivation affects the performance of pilots. Work motivation is reflected in cooperative behavior with coworkers and disciplined motivation provided by proven superiors can improve pilot performance. The results showed that good cooperation with coworkers was able to form a work motivation of pilots. Military pilots in their daily lives are never separated from the conditions of cooperation with colleagues. The good motivation provided by superiors, proven to grow the pilots feel happy and excited at work. Highly motivated pilots show a positive attitude to work, show genuine concern for work and help pilots work better, always maintain a balanced attitude in various situations, motivate others and always think positively of an event.

\section{Organizational climate and pilot performance}

The results of the study prove that Organizational climate influences the performance of pilots. The more conducive organizational climate, the positive impact on pilot performance. Structures that describe tasks and roles in work and the climate built by each pilot responsible for work can improve pilot performance. The division of tasks and a clear role in the world of aviation work can improve performance. In addition to being proven that pilots have the responsibility for the work provided by superiors, it contributes to creating a good work climate and leads to the performance of other pilots. Organizational climate is a description of the environment and the nature of the work environment that exists in an organization where pilots do their work both pleasant and unpleasant. Organizational climate is closely related to the process of creating a conducive work environment to create harmonious relationships and cooperation between all individuals who are in the organization. The conducive organizational climate can be a tool for leaders to motivate pilots in completing work.

\section{Transformational Leadership and pilot performance} The results of the study prove that Transformational leadership influences the performance of pilots. Leadership willingness to listen to problems experienced by subordinates, special attention from leaders, and support for enthusiasm for achievement greatly impacted the performance of pilots. The Indonesian Air Force Pilot at the $2^{\text {nd }}$ Air Wing had implemented the principles of constructive leadership. This is demonstrated by understanding the disciplinary behavior of the pilots, being a role model, decisiveness in decision making, and being brave of the risks to be faced. Besides, leaders have extensive knowledge of basic tasks and functions, the right instincts for action, sensitivity to pilot conditions, ability to educate subordinates, rational and objective attitudes, actively participate to strengthen pilot unity, and be proactive in developing pilots' careers. Successful leadership, achieved by choosing the right leadership style, is dependent on the level of readiness or maturity of its followers.

\section{CONCLUSIONS AND RECOMMENDATIONS}

The test results on the effect of individual capability, individual motivation, organizational climate, and transformational leadership on the performance of pilots show that individual capability 
has a superior role in determining the pilot performance of the Indonesian Air Force at the $2^{\text {nd }}$ Air Wing. Their performance was shaped by the ability of the Pilot NonTechnical Skill (NTS) reflected in the ability of the pilots in the situation of "Awareness" in-flight implementation. It is very important for the implementation of any type of aircraft flight that this point (NTS) is crucial for the safety of the pilots.

For future researchers, the perceptions of pilots between Non-Technical Skill Pilots and safety need to be studied in more depth. Triatmanto et al. [25, 26] suggest conducting studies and testing human resources competence and emotional skills related to human resources-based performance.This study needs to be done for efforts to prevent accidental aircraft that are not desired by anyone.

\section{REFERENCES}

1. Tippe, S. (2012). Human Capital pada organisasi Militer.

2. Evaluation of Wing 2, (2016). Work Report. TNI AU

3. Mayo, A. (2000). The Role of Employee Development in the Growth of Intellectual Capital. Personnel Review, 29(4), 521-533.

4. Wiener, K., Helmreich, \& Jan (2010). Crew Resource Management. 2nd Edition.

5. Nadeem, M. T., Zia-ud-Din, M., \& Zubair, M. (2018). The Impact of Employees Capabilities on Organizational Legitimate Interest. International Journal of Academic Research in Business and Social Sciences, 8(6).

6. Mangkunegara, A. P., \& Prabu, A. (2009). Manajemen sumber daya manusia. Bandung: $P T$. Remaja Rosdakarya.

7. Nugraha, P. C., Susilo, H., \& Aini, E. K. (2018). Pengaruh human capital terhadap kinerja perusahaan (Studi pada Perusahaan Advertising dan Periklanan Malang yang Terdaftar pada Asosiasi Advertising dan Periklanan Malang). Jurnal Administrasi Bisnis, 57(2), 180189.

8. Mathis, R., \& Jackson, J. (2002). Manajemen Sumber Daya Manusia. Jakarta: Salemba empat.

9. Simamora, H. (2010). Manajemen Sumber Daya Manusia. Cetakan Kedua. Yogyakarta: Aditya Media.

10. Triatmanto, H. R. B. (2019). Reward System as a Strategic HRM Determining Work Productivity in Hospitality Organizations.
11. Bass, B.M., \& Avolio. (1993). Transformational Leadership and Organizational Culture. Public Administration Quarterly.

12. Rufino. (2010). Peran Kepemimpinan, Motivasi dan lingkungan kerja terhadap kinerja karyawan Grand Manhattan Club.

13. Heru. (2012). Kompetensi, motivasi, peran kepemimpinan, dan Kinerja pegawai direktorat jenderal Perdagangan dalam negeri.

14. Soegiarto. (2016). Pengaruh Kepemimpinan Transformasional terhadap Kinerja Karyawan Pada CV. Norton Surabaya. Agora, 4(2): 320-327.

15. Ruky, Achmad, S. (2002). Sistem Manajemen kinerja. Jakarta: PT Bumi Aksara.

16. Dessler, G. (2009). Manajemen SDM. buku 1. Jakarta: Indeks.

17. ICAO Annex 2, Rules of the air, Tenth Edition, pp2-1, (July 2005)

18. Fred Miao, C., \& Evans, K. R. (2007). The impact of salesperson motivation on role perceptions and job performance - a cognitive and affective perspective. Journal of Personal Selling \& Sales Management, 27(1), 89-101.

19. Maurino, V. G., Drincovich, M. F., \& Andreo, C. S. (1996). NADP-malic enzyme isoforms in maize leaves. Biochemistry and molecular biology international, 38(2), 239-250.

20. Robbins, S.P., \& Judge. (2002). Perilaku Organisasi. Buku 2, Jakarta: Salemba.

21. Fernet, C., Guay, F., Senécal, C., \& Austin, S. (2012). Predicting intraindividual changes in teacher burnout: The role of perceived school environment and motivational factors. Teaching and teacher education, 28(4), 514-525.

22. Stringer, R. (2002). Leadership and Organizational Climate. Prentice-Hall. New Jersey

23. Bass, B.M. (1985). Leadership and Performance beyond Expectations, Free Press, New York, NY.

24. Bass, B.M. (1997). Does the TransactionalTransformational Leadership Paradigm Transcend Organizational and National Boundaries?. Journal American Psychologist, 52: 130-139.

25. Triatmanto, B., Wahyuni, N., \& Respati, H. (2019). Continual human resources empowerment through human capital and commitment for the organizational performance in hospitality industry. Quality Acses to Sucses, 20(173), 84-91.

26. Junandi, S. (2012). Pengaruh iklim organisasi terhadap kinerja pustakawan Universitas Gadjah Mada $=$ The influence of organizational climate for librarian's performance in Gadjah Mada University. SANGKAKALA, 12, 24-33. 